\title{
Pengaruh Penggunaan dan Perhitungan Efisiensi Bahan Bakar Premium dan Pertamax Terhadap Unjuk Kerja Motor Bakar Bensin
}

\author{
Sugeng Mulyono ${ }^{1)}$ Gunawan $^{2)}$ Budha Maryanti ${ }^{3)}$ \\ Program Studi Teknik Mesin Fakultas Teknologi Industri Universitas Balikpapan \\ Jl. Pupuk Raya PO BOX 335 Balikpapan \\ Email : budha_maryanti@yahoo.com, gun.salsa@gmail.com
}

\begin{abstract}
Public service vehicles such as motorcycles can currently use some type of fuel choices for gasoline motors of Pertamina include premium and pertamax. Each type of fuel has different an octane number. The performance of the motor is heavily influenced by several factors; one of them is type of fuel used. The purpose of this study was to determine the difference effect octane number of the gasoline fuel performance torque, power, and to analyze the specific fuel consumption of the motor 4 gear.

This experiment tries to test motor performance, torque, power and then analyzed fuel used especially Pertamina product such as premium gasoline and pertamax. Each type of motor gasoline was tested on $108 \mathrm{cc}$ Honda type Beat 2012 using dynotest, which is connected to the computer. The computer will record chart changes in torque and increase power of the engine rotation of $500 \mathrm{rpm}$ to $9500 \mathrm{rpm}$. Meanwhile the specific fuel consumption is calculated based on the time required to spend any fuel that is tested. This study was conducted at a laboratory of Surabaya University.

The results showed the maximum torque is achieved at the gasoline pertamax of $116.15 \mathrm{Nm}$ at 2000 rpm rotation, followed by a mixture between $50 \%$ pertamax and $50 \%$ premium $99.93 \mathrm{Nm}$ at $2500 \mathrm{rpm}$ rotation, and premium gasoline $67.53 \mathrm{Nm}$ at $2500 \mathrm{rpm}$. Meanwhile, on the maximum power of gasoline pertamax is 6.6 $\mathrm{HP}$ at $4000 \mathrm{rpm}$ and $4500 \mathrm{rpm}$, followed by $6.5 \mathrm{HP}$ gas mixtures at $3500 \mathrm{rpm}$ rotation until $4500 \mathrm{rpm}$ and 5500 rpm rotation, and a premium of $6.4 \mathrm{HP}$ at $5500 \mathrm{rpm}$ rotation. For a minimum specific fuel consumption of 0.41 $\mathrm{kg}$ pertamax owned / $\mathrm{kwh}$ at $3500 \mathrm{rpm}$ rotation until $5500 \mathrm{rpm}$, followed by premium gasoline by $0.48 \mathrm{~kg} / \mathrm{kWh}$ at $5500 \mathrm{rpm}$, then the gas mixture of $0.53 \mathrm{~kg} / \mathrm{kWh}$ at $3500 \mathrm{rev}$ rpm to $4500 \mathrm{rpm}$.
\end{abstract}

Keywords : Torque, Power, and Specific fuel consumption

\begin{abstract}
Abstrak
Kendaraan umum seperti sepeda motor saat ini bisa menggunakan beberapa pilihan jenis bahan bakar Pertamina untuk motor bensin antara lain Premium dan Pertamax. Masing-masing jenis bahan bakar tersebut memiliki angka oktan yang berbeda. Unjuk kerja motor banyak dipengaruhi oleh beberapa faktor, di antaranya jenis bahan bakar yang digunakan. Tujuan dari penelitian ini adalah untuk mengetahui pengaruh perbedaan angka oktan bahan bakar bensin terhadap unjuk kerja torsi, daya, dan kemudian menganalisa konsumsi bahan bakar spesifik pada motor 4 tak.

Pada percobaan ini diuji unjuk kerja motor mengenai torsi, daya, dan kemudian menganalisa konsumsi bahan bakar spesifik yang digunakan pada bensin produksi Pertamina yang biasa digunakan, antara lain bensin premium dan pertamax. Masing-masing jenis bensin diuji pada motor Honda jenis Beat 108 cc tahun 2012 dengan menggunakan Dynotest, yang terhubung dengan komputer. Komputer akan mencatat grafik perubahan torsi dan daya terhadap kenaikan putaran mesin dari 500 rpm hingga 9500 rpm. Sedangkan konsumsi bahan bakar spesifik dihitung berdasarkan waktu yang diperlukan dalam menghabiskan setiap bahan bakar yang diuji. Penelitian ini dilakukan di laboratorium teknik mesin universitas Negeri Surabaya.

Hasil penelitian menunjukkan torsi maksimum dicapai pada bensin pertamax sebesar $116.15 \mathrm{Nm}$ pada putaran 2000 rpm, diikuti campuran antara 50\% pertamax dan 50\% premium $99.93 \mathrm{Nm}$ pada putaran 2500 rpm, dan bensin premium 67,53 Nm pada 2500 rpm. Sedangkan daya maksimum juga pada bensin pertamax sebesar 6,6 HP pada 4000 rpm dan 4500 rpm, diikuti bensin campuran 6,5 HP pada putaran 3500 rpm sampai $4500 \mathrm{rpm}$ dan putaran $5500 \mathrm{rpm}$, lalu premium sebesar 6,4 HP pada putaran $5500 \mathrm{rpm}$. Untuk konsumsi bahan bakar spesifik minimal dimiliki pertamax sebesar $0,41 \mathrm{~kg} / \mathrm{kwh}$ pada putaran $3500 \mathrm{rpm}$ sampai 5500 rpm, diikuti bensin premium sebesar 0,48 kg/kwh pada $5500 \mathrm{rpm}$, kemudian bensin campuran sebesar 0,53 $\mathrm{kg} / \mathrm{kWh}$ pada putaran $3500 \mathrm{rpm}$ sampai $4500 \mathrm{rpm}$.
\end{abstract}

Kata Kunci : Torsi, Daya, dan Konsumsi Bahan Bakar Spesifik 


\section{Pendahuluan}

Bensin atau petrolium adalah cairan campuran yang berasal dari minyak bumi dan sebagian besar tersusun dari hidrokarbon serta digunakan dalam mesin pembakaran dalam sebagai bahan bakar.

Umumnya kendaraan di Indonesia saat ini menggunakan beberapa pilihan jenis bahan bakar Pertamina untuk motor bensin antara lain Premium dan Pertamax. Masing-masing jenis bahan bakar tersebut memiliki angka oktan yang berbeda. Angka oktan menunjukan berapa besar tekanan maksimum yang dapat diberikan di dalam mesin sebelum bensin terbakar secara spontan. Pada tekanan tertentu bahan bakar akan menyala seiring adanya tekanan pada piston yang menaikkan temperatur di dalam silinder. Penyalaan yang diakibatkan tekanan ini tidak dikehendaki karena dapat menyebabkan detonasi. Penyalaan yang baik disebabkan dari pengapian busi.

Oleh sebab itu dengan penggunaan bahan bakar yang sesuai dengan perbandingan kompresi yang tepat untuk mesin yang digunakan, diharapkan akan mengoptimalkan kinerja mesin, mengurangi kerusakan dan yang lebih penting lagi akan dapat mengefisiensikan penggunaan bahan bakar.

Tujuan penelitian ini untuk mengetahui torsi maksimum dan daya maksimum dari penggunaan bahan bakar jenis premium, pertamax dan campuran serta pengaruhnya terhadap unjuk kerja motor Honda Beat Matic 108 cc.

Lukman Hakim, (2004) $)^{[1]}$ telah meneliti tentang pengaruh penggunaan berbagai jenis bahan bakar (Premium, Pertamax dan Pertamax Plus) terhadap unjuk kerja motor bensin 4 langkah. Setelah dilakukan pengujian diperoleh bahwa penggunaan berbagai jenis bahan bakar (Premium, Pertamax dan Pertamax Plus) tidak memberikan pengaruh yang sangat nyata terhadap torsi dan daya efektif yang dihasilkan oleh motor bensin 4 langkah. dimana unjuk kerja yang dihasilkan dari ketiga jenis varian bahan bakar tersebut cenderung memberikan hasil yang sama.

Tri Hartono, Subroto, dan Nur Aklis, (2011) ${ }^{[2]}$ meneliti mengenai pengaruh penggunaan bahan bakar premium, pertamax dan pertamax plus terhadap unjuk kerja motor bakar bensin dimana mereka melakukan pengujian pada motor Honda jenis Supra X 100 cc tahun 2001 dengan alat dynotest. Hasil pengujian menunjukkan torsi maksimum dan daya maksimum dicapai dengan penggunaan bensin pertamax, sedangkan Untuk konsumsi bahan bakar spesifik minimal dimiliki pertamax plus.

Pada motor bensin untuk mendapatkan energi termal diperlukan proses pembakaran dengan menggunakan campuran bahan bakar dan udara di dalam mesin, sehingga motor bensin disebut juga sebagai motor pembakaran dalam (Internal Combustion Engine). Di dalam proses pembakaran ini gas hasil pembakaran yang terjadi sekaligus berfungsi sebagai fluida kerja. Prinsip kerja dari motor bensin adalah berdasar siklus udara pada volume konstan (Otto cycle) atau biasa disebut siklus ideal motor bensin. Dalam kenyataannya siklus ideal ini sulit terjadi.

Perbandingan kompresi mesin dirancang sesuai dengan aplikasi dan bahan bakar yang akan digunakan. Pertanyaan yang banyak muncul sekarang ini di antara pemakai kendaraan bermotor adalah apa akibatnya apabila menggunakan bensin premium atau beroktan lebih rendah. Pasalnya, harga bensin beroktan tinggi sekarang ini semakin cepat menguras kantong.

Beberapa Produsen kendaraan bermotor, membuat mesin dengan perbandingan kompresi yang tinggi, hal ini bertujuan untuk meningkatkan efisiensi atau dapat dikatakan irit bahan bakar dan menurunkan kadar emisi.

Untuk membuat mesin bekerja dengan perbandingan kompresi tinggi, syarat utamanya adalah harus menggunakan bensin dengan oktan 
lebih tinggi. Kendati demikian,tidak semua mesin harus atau lebih baik menggunakan bensin beroktan tinggi. Mesin dengan kompresi rendah, jika diberi bensin oktan tinggi, hanya menyebabkan pemborosan uang. Tenaga mesin juga tidak naik dan tetap saja boros. Sebenarnya para ahli yang berkecimpung di laboratorium mesin sudah mengeluarkan data hubungan antara perbandingan kompresi dan oktan bahan bakar seperti berikut.

Tabel 1. Perbandingan Kompresi dan Oktan Bahan Bakar ${ }^{[3}$

\begin{tabular}{|c|c|c|}
\hline $\begin{array}{c}\text { Perbanding } \\
\text { an } \\
\text { Kompresi }\end{array}$ & $\begin{array}{c}\text { Kebutuhan } \\
\text { Nilai Oktan }\end{array}$ & $\begin{array}{c}\text { Efisiensi } \\
\text { Termal \% } \\
\text { (Gas } \\
\text { ditekan } \\
\text { habis) }\end{array}$ \\
\hline $5: 1$ & 72 & - \\
\hline $6: 1$ & 81 & 25 \\
\hline $7: 1$ & 87 & 30 \\
\hline $8: 1$ & 92 & 32 \\
\hline $9: 1$ & 96 & 33 \\
\hline $10: 1$ & 100 & \\
\hline
\end{tabular}

Ukuran yang ditunjukkan dari tabel 1 adalah ukuran idealnya, tetapi pada sebagian mesin sekarang, apalagi ada yang menggunakan dua busi atau ada pula dengan sistem busi menyala dua kali secara berurutan atau penambahan part racing yang mendukung pengapian, penggunaan bensin beroktan lebih rendah masih bisa digunakan pada kompresi yang bukan pada tempatnya.

Oktan dicampurkan ke dalam bensin berfungsi untuk mencegah agar jangan cepat terbakar. Pada mesin, waktu pembakaran (pengapian) telah ditentukan berdasarkan siklus atau langkah kerja mesin.

Besar angka oktan bahan bakar dapat diukur dengan mesin CFR (Coordinating Fuel Research). Sebagai contoh premium mempuyai mempunyai Research Octane Number (RON) sebesar 88 dan pertamax mempuyai Research Octane Number (RON) sebesar 92.

Bensin premium adalah bensin yang telah diberi TEL (tetra ethyl lead) dan bernilai oktan 88 . Premium adalah bahan bakar minyak jenis distilat berwarna kekuningan yang jernih. Bensin premium mempuyai sifat anti ketukan yang baik dan dapat dipakai pada mesin dengan batas kompresi hingga 9,0:1 pada semua jenis dan kondisi, namun tidak baik jika digunakan pada motor bensin dengan kompresi tinggi karena dapat menyebabkan knocking. Knocking dapat dikurangi dengan menambahkan zat additive, seperti TEL (tetra ethyl lead, $\left.\mathrm{Pb}\left(\mathrm{C}_{2} \mathrm{H}_{5}\right)_{4}\right)$, $\operatorname{MTBE}($ methyl tertiarybutyl, ether, $\left.\mathrm{C}_{5} \mathrm{H}_{11} \mathrm{O}\right)$, atau etanol dalam bahan bakar tersebut

Bensin premium produk Pertamina memiliki kandungan maksimum sulfur (S) 0,05\%, timbal $(\mathrm{Pb})$ 0,013\% (jenis tanpa timbal) dan $\mathrm{Pb} 0,3 \%$ (jenis dengan timbal), oksigen (O) 2,72\%, pewarna $0,13 \mathrm{gr} / 100$ $\mathrm{L}$, tekanan uap $62 \mathrm{kPa}$, titik didih $215^{\circ} \mathrm{C}$, serta massa jenis (suhu $15^{\circ} \mathrm{C}$ ) $715 \div 780$ $\mathrm{kg} / \mathrm{m}^{3}$.

Pertamax merupakan jenis bahan bakar dengan angka oktan 92. Bensin pertamax dianjurkan digunakan untuk kendaraan bahan bakar bensin yang mempunyai perbandingan kompresi tinggi $(9,1: 1$ sampai 10,0 : 1). Pada bahan bakar pertamax ditambahkan aditif sehingga mampu membersihkan mesin dari timbunan deposit pada fuel injector dan ruang pembakaran.

Bahan bakar pertamax sudah tidak menggunakan campuran timbal sehingga dapat mengurangi racun gas buang kendaraan bermotor seperti nitrogen oksida dan karbon monooksida.

Bensin pertamax berwarna kebiruan dan 
memiliki kandungan maksimum sulfur (S) $0,1 \%$, timbal $(\mathrm{Pb}) 0,013 \%$ (jenis tanpa timbal) dan $\mathrm{Pb} 0,3 \%$ (jenis dengan timbal), oksigen $(\mathrm{O}) 2,72 \%$, pewarna $0,13 \mathrm{gr} / 100$ $\mathrm{L}$, tekanan uap $45 \div 60 \mathrm{kPa}$, titik didih 205 ${ }^{\circ} \mathrm{C}$, serta massa jenis (suhu $15^{\circ} \mathrm{C}$ ) $715 \div$ $780 \mathrm{~kg} / \mathrm{m}^{3}$.

Daya motor merupakan salah satu parameter dalam menentukan performa motor. Perbandingan perhitungan daya terhadap bebagai macam motor tergantung pada putaran mesin dan momen putar itu sendiri, semakin cepat putaran mesin, rpm yang dihasilkan akan semakin besar sehingga daya yang dihasilkan juga semakin besar, begitu juga momen putar motornya, semakin banyak jumlah gigi pada roda giginya semakin besar torsi yang terjadi. Dengan demikian jumlah putaran (rpm) dan besarnya momen putar atau torsi mempengaruhi daya motor yang dihasilkan oleh sebuah motor.

Pada motor bakar daya yang berguna adalah daya poros, dikarenakan poros tersebut menggerakan beban. Dengan demikian besar daya poros itu adalah ${ }^{[4]}$.

$$
P=\frac{2 \pi \cdot n \cdot T}{60000}(k W)
$$

Dimana : $\mathrm{P}=$ daya $(\mathrm{kW})$

$$
\begin{aligned}
& \mathrm{T}=\operatorname{torsi}(\mathrm{Nm}) \\
& \mathrm{n}=(\mathrm{rpm})
\end{aligned}
$$

Torsi adalah ukuran kemampuan mesin untuk melakukan kerja, jadi torsi adalah suatu energi. Torsi dapat diperoleh dari hasil kali antara gaya dengan jarak ${ }^{[5]}$ :

$$
\mathrm{T}=\mathrm{F} \times \mathrm{S}
$$

$$
\begin{aligned}
\text { Dimana }: & \mathrm{T}=\operatorname{torsi}(\mathrm{Nm}) \\
\mathrm{F} & =\operatorname{gaya} \text { sentrifugal }(\mathrm{N}) \\
\mathrm{S} & =\operatorname{jarak}(\mathrm{m})
\end{aligned}
$$

Torsi pada pengujian dengan alat dynamometer diperoleh dari daya motor yang memutar roda belakang motor yang bersinggungan dengan silinder pejal sebagai beban. Pada silinder ini terdapat sensor yang dihubungkan dengan alat konsul GUI yang selanjutnya diterjemahkan pada komputer.

Perhitungan konsumsi bahan bakar spesifik ini digunakan untuk mengetahui jumlah bahan bakar yang dibutuhkan untuk menghasilkan daya dalam waktu tertentu. Jika daya dalam satuan $\mathrm{kW}$ dan laju aliran massa bahan bakar dalam satuan $\mathrm{kg} / \mathrm{jam}$ maka konsumsi bahan bakar spesifik dapat dirumuskan ${ }^{[6]}$ :

$$
S F C=\frac{m_{f}}{P}(k g / k W h)
$$

Dimana : $\quad$ SFC $=$ konsumsi bahan bakar spesifik

$$
\begin{aligned}
& { }_{m_{f}} \quad(\mathrm{~kg} / \mathrm{kWh}) \\
& (\mathrm{kg} / \mathrm{jam}) \\
& \mathrm{P}=\text { konsumsi bahan bakar } \\
&
\end{aligned}
$$

Sedangkan besarnya laju aliran massa bahan bakar $\left(\mathrm{m}_{f}\right)$ dihitung dengan persamaan sebagai berikut ${ }^{[7]}$ :

$\mathrm{m}_{f}=\frac{\mathrm{S}_{g f} \times \mathrm{V}_{f} \times 10^{-3}}{(4)} \times 3600$

(4)

$\mathrm{t}_{f}$

Dimana $:{ }_{f}^{m}=$ Konsumsi bahan bakar (kg/jam)

$\mathrm{S}_{g f}=$ Spesifik grafity $(\mathrm{gr} / \mathrm{ml})$.

$\mathrm{S}_{g f}$ Bensin adalah $0.715 \mathrm{gr} / \mathrm{ml}$

$V_{f}=$ Volume bahan bakar yang

diuji

(ml).

$\mathrm{t}_{f}=$ Waktu untuk menghabiskan

bahan

bakar yang diuji (detik)

\section{Waktu, Tempat dan Metode Penelitian}

Penelitian dilakukan pada bulan April s/d Juli 2013 di laboratorium teknik mesin Universitas Negeri Surabaya.

Penelitian ini menggunakan metode eksperimental. Penelitian ini 
dititikberatkan pada perbandingan unjuk kerja mesin yang didapatkan melalui variabel-variabel yang diukur untuk performa mesinnya meliputi : putaran/rpm, torsi, daya, serta menghitung penggunaan konsumsi bahan bakar terhadap putaran mesin.

Bahan dan alat yang digunakan antara lain:

Bahan : premium dan pertamax, masingmasing memerlukan 2 liter.

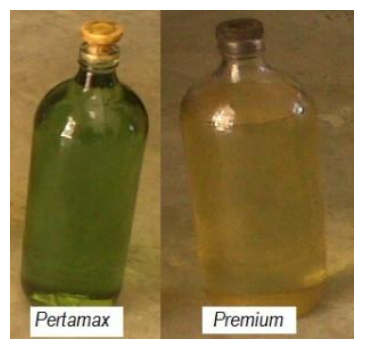

Gambar 1. Bahan bakar yang digunakan

Alat yang digunakan yaitu dynotest untuk mendapatkan data torsi dan daya (Horse Power) dari suatu mesin, komputer serta alat tambahan berupa gelas ukur yang digunakan untuk mengukur volume bahan bakar.

Ada dua tahapan persiapan pengujian ini sebelum dilakukan pengujian yaitu :

a. Persiapan dan pemeriksaan bagian mesin uji :

1. Melakukan pengecekan kondisi mesin uji yang meliputi : kondisi minyak pelumas mesin, busi, dan kabel-kabel sistem kelistrikan yang lainnya.

2. Melakukan servis atau tune up pada mesin uji yang meliputi penyetelan karburator dan penyetelan katup.

b. Persiapan dan pemeriksaan bagian alat uji :

1. Memeriksa Pemasangan alat uji dan perangkat alat uji.

2. Menyiapkan dan memeriksa alat ukur dan alat-alat tambahan (stopwatch dan alat tulis untuk mencatat data).

3. Memeriksa selang dan sambungan untuk memastikan tidak terdapat kebocoran ataupun hal yang lain yang dapat menghambat proses pengujian.
4. Memastikan semua peralatan uji atau instrumen bisa bekerja dengan baik untuk mendapatkan hasil yang optimal dan menghindarkan terjadinya kecelakaan kerja.

\section{Hasil dan Pembahasan}

Tahap Pengambilan Data Torsi dan Daya

1. Pastikan jenis bensin (premium dan pertamax) yang akan digunakan sesuai dan cukup untuk proses pengujian.

2. Mesin motor dinyalakan untuk dilakukan pemanasan, yaitu pada posisi idle speed.

3. Setelah mesin motor dinyalakan pada monitor komputer akan menampilkan Gauges Windows / Dyno Run yang mengukur perubahan putaran (rpm) dan kecepatan roda motor $(\mathrm{km} / \mathrm{jam})$.

4. Setelah dilakukan pemanasan pada mesin selama kira-kira 3-5 menit, kemudian mengatur atau memutar throttle secara perlahan sehingga putaran awal mesin sebesar $1500 \mathrm{rpm}$ dan biarkan beberapa saat supaya putaran tersebut stabil.

5. Pada komputer masukkan data suhu dan kelembaban ruangan pada tiap pengambilan data..

6. Naikkan putaran mesin dengan memutar throttle hingga putaran mesin maksimal ( \pm 9000-9500 rpm), dengan penambahan variasi putaran $500 \mathrm{rpm}$

7. Pada rentang putaran tersebut perubahan data dapat dilihat dari komputer. Data yang dapat diperoleh berupa tabel dan grafik perubahan putaran, daya (HP) dan torsi (N.m) pada tiap putaran tertentu.

8. Dan pada waktu perubahan volume bensin pada skala buret tiap $5 \mathrm{ml}$ dicatat dengan stopwatch.

9. Untuk mengakhiri percobaan ini putaran mesin diturunkan dengan memutar throttle secara perlahan, hingga posisi normal, kemudian matikan mesin. 
10. Bahan bakar yang digunakan diganti (Premium dan Campuran antara 50\% Premium dan 50\% Pertamax), kemudian lakukan langkah-langkah percobaan dan pengambilan data seperti di atas..

\section{Hasil dan pembahasan}

Tabel 2. Hasil pengujian bahan bakar jenis pertamax

\begin{tabular}{||c||c||c||}
\hline $\begin{array}{c}\text { Putaran } \\
\text { Poros, } \\
\text { n (rpm) }\end{array}$ & $\begin{array}{c}\text { Daya, } \\
\text { (hasil } \\
\text { percobaan }) \\
\text { P (KW) }\end{array}$ & $\begin{array}{c}\text { Torsi, } \\
\text { (hasil } \\
\text { percobaan) } \\
\text { T (Nm) }\end{array}$ \\
\hline \hline 500 & 0.2 & 15.19 \\
\hline 1000 & 0.8 & 39.42 \\
\hline 1500 & 2.9 & 93.04 \\
\hline 2000 & 4.8 & 116.15 \\
\hline 2500 & 5.6 & 104.48 \\
\hline 3000 & 6.2 & 95.08 \\
\hline 3500 & 6.5 & 85.99 \\
\hline 4000 & 6.6 & 76.08 \\
\hline 4500 & 6.6 & 67.28 \\
\hline 5000 & 6.5 & 59.74 \\
\hline 5500 & 6.5 & 54.52 \\
\hline 6000 & 6.4 & 48.69 \\
\hline 6500 & 6.3 & 44.10 \\
\hline 7000 & 5.8 & 37.94 \\
\hline 7500 & 5.7 & 34.38 \\
\hline 8000 & 5.7 & 32.25 \\
\hline 8500 & 5.3 & 28.38 \\
\hline 9000 & 4.8 & 24.45 \\
\hline 9500 & 3.1 & 14.66 \\
\hline
\end{tabular}

Tabel 3. Hasil pengujian bahan bakar jenis Pertamax 50\% + Premium 50\%

\begin{tabular}{|c|c|c|}
\hline $\begin{array}{c}\text { Putaran } \\
\text { Poros, } \\
\mathrm{n}(\mathrm{rpm})\end{array}$ & $\begin{array}{c}\text { Daya, (hasil } \\
\text { percobaan) } \\
\mathrm{P}(\mathrm{KW})\end{array}$ & $\begin{array}{c}\text { Torsi, (hasil } \\
\text { percobaan) } \\
\mathrm{T}(\mathrm{Nm})\end{array}$ \\
\hline 1500 & 1.7 & 55.00 \\
\hline 2000 & 4.0 & 95.20 \\
\hline 2500 & 5.4 & 99.93 \\
\hline 3000 & 6.2 & 95.91 \\
\hline 3500 & 6.5 & 85.88 \\
\hline 4000 & 6.5 & 74.65 \\
\hline
\end{tabular}

\begin{tabular}{|l|l|l|}
\hline 4500 & 6.5 & 66.10 \\
\hline 5000 & 6.4 & 58.45 \\
\hline 5500 & 6.5 & 53.59 \\
\hline 6000 & 6.4 & 48.18 \\
\hline 6500 & 6.1 & 42.80 \\
\hline 7000 & 5.7 & 37.14 \\
\hline 7500 & 5.6 & 34.06 \\
\hline 8000 & 5.7 & 32.50 \\
\hline 8500 & 5.2 & 27.90 \\
\hline 9000 & 4.8 & 23.90 \\
\hline
\end{tabular}

Tabel 4 Hasil pengujian bahan bakar jenis premium

\begin{tabular}{||c||c||c||}
\hline $\begin{array}{c}\text { Putaran } \\
\text { Poros, } \\
\mathrm{n}(\mathrm{rpm})\end{array}$ & $\begin{array}{c}\text { Daya, (hasil } \\
\text { percobaan) } \\
\mathrm{P}(\mathrm{KW})\end{array}$ & $\begin{array}{c}\text { Torsi, (hasil } \\
\text { percobaan) } \\
\mathrm{T}(\mathrm{Nm})\end{array}$ \\
\hline \hline 1000 & 0.3 & 12.87 \\
\hline 1500 & 1.7 & 52.79 \\
\hline 2000 & 2.7 & 62.33 \\
\hline 2500 & 3.7 & 67.53 \\
\hline 3000 & 4.3 & 66.10 \\
\hline 3500 & 4.6 & 59.76 \\
\hline 4000 & 4.6 & 52.85 \\
\hline 4500 & 5.2 & 52.70 \\
\hline 5000 & 6.0 & 54.73 \\
\hline 5500 & 6.4 & 53.29 \\
\hline 6000 & 6.3 & 47.48 \\
\hline 6500 & 6.2 & 43.29 \\
\hline 7000 & 5.8 & 37.79 \\
\hline 7500 & 5.8 & 34.94 \\
\hline 8000 & 5.3 & 30.23 \\
\hline 8500 & 5.4 & 28.62 \\
\hline 9000 & 4.9 & 24.37 \\
\hline
\end{tabular}

\section{Hubungan Torsi (T) Terhadap Putaran} (n)

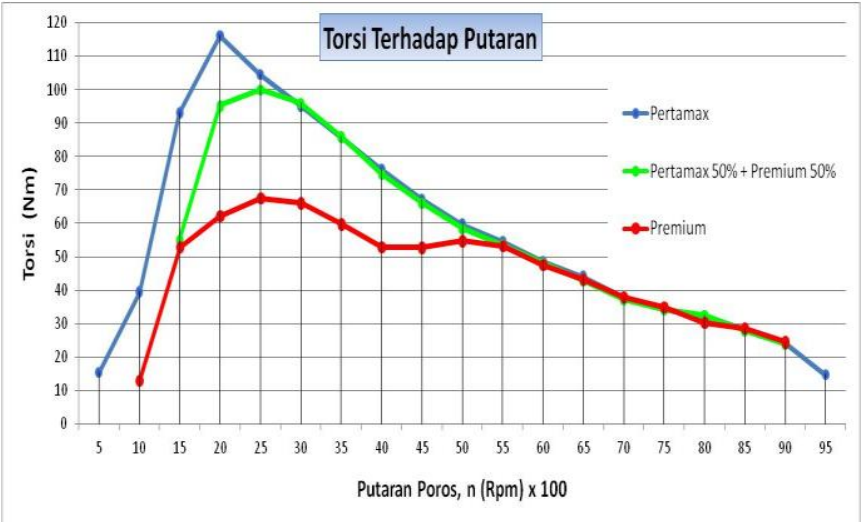


Gambar 2 Grafik perbandingan bahan bakar terhadap torsi dan putaran

Dari grafik diatas menunjukkan hubungan torsi terhadap putaran dimana kenaikan torsi seiring dengan meningkatnya putaran untuk setiap konsentrasi. Untuk konsentrasi pertamax $100 \%$ menunjukan bahwa torsi maksimum dicapai adalah $115.16 \mathrm{Nm}$ pada putaran $2000 \mathrm{rpm}$, dan torsi minimum adalah $14.66 \mathrm{Nm}$ yang dicapai pada putaran 9500 rpm. Sedangkan pada konsentrasi campuran pertamax $50 \%$ + premium $50 \%$ torsi maksimum dicapai adalah $99.93 \mathrm{Nm}$ pada putaran $2500 \mathrm{rpm}$ dan torsi minimum adalah $23.9 \mathrm{Nm}$ yang dicapai pada putaran $9000 \mathrm{rpm}$. Dan pada konsentrasi premium $100 \%$ menunjukan bahwa torsi maksimum adalah $67.53 \mathrm{Nm}$ yang dicapai pada putaran yang sama pada bahan bakar campuran $\quad(50 \%$ Pertamax dan $50 \%$ Premium) yaitu $2500 \mathrm{rpm}$ dan torsi minimum dicapai adalah $12.87 \mathrm{Nm}$ pada putaran $1000 \mathrm{rpm}$.

\section{Hubungan Daya (P) Terhadap Putaran} (n)

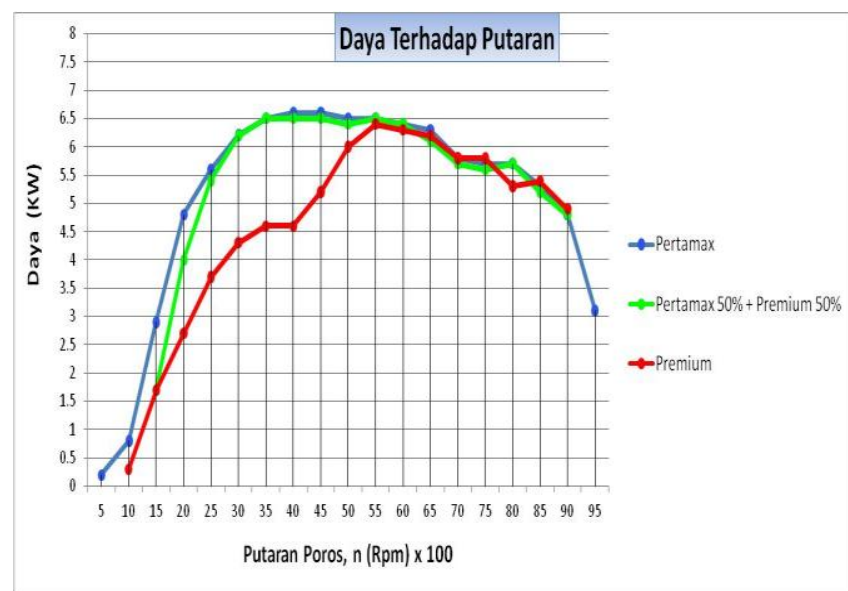

Gambar 3. Grafik perbandingan bahan bakar terhadap daya dan putaran

Dari grafik diatas menunjukkan hubungan daya terhadap putaran. Untuk konsentrasi pertamax $100 \%$ menunjukan bahwa daya maksimum dicapai adalah 6.6
KW pada putaran 4000-4500 rpm dan daya minimum adalah $0.2 \mathrm{KW}$ pada putaran 500 rpm.Sedangkan pada konsentrasi campuran pertamax $50 \%+$ premium $50 \%$ daya maksimum yang dicapai adalah $6.5 \mathrm{KW}$ pada putaran 30004500 rpm dan pada putaran 5500 rpm untuk daya minimum dicapai adalah 1.7 KW pada putaran 1500 rpm.Pada konsentrasi premium $100 \%$ menunjukan bahwa daya maksimum dicapai adalah 6.4 KW pada putaran $5500 \mathrm{rpm}$ dan daya minimum yang dicapai adalah 0.3 pada putaran $1000 \mathrm{rpm}$.

\section{Hubungan Konsumsi Bahan Bakar Spesifik (SFC) Terhadap Putaran (n)}

Tabel 5 Hubungan konsumsi bahan bakar terhadap putaran

\begin{tabular}{||c|c|c|c||}
\hline \multirow{2}{*}{$\begin{array}{c}\text { Putaran } \\
\text { Poros, n } \\
\text { (rpm) }\end{array}$} & \multicolumn{3}{|c||}{ Konsumsi Bahan Bakar Spesifik } \\
\cline { 2 - 4 } & Pertamax & $\begin{array}{c}\text { Campuran } \\
50 \% \\
\text { Premium } \\
\text { dan 50\% } \\
\text { Pertamax }\end{array}$ & Premium \\
\hline \hline 500 & 13.41 & - & - \\
\hline 1000 & 3.35 & - & 10.31 \\
\hline 1500 & 0.92 & 2.03 & 1.82 \\
\hline 2000 & 0.56 & 0.86 & 1.15 \\
\hline 2500 & 0.48 & 0.64 & 0.84 \\
\hline 3000 & 0.43 & 0.56 & 0.72 \\
\hline 3500 & 0.41 & 0.53 & 0.67 \\
\hline 4000 & 0.41 & 0.53 & 0.67 \\
\hline 4500 & 0.41 & 0.53 & 0.59 \\
\hline 5000 & 0.41 & 0.54 & 0.52 \\
\hline 5500 & 0.41 & 0.53 & 0.48 \\
\hline 6000 & 0.42 & 0.54 & 0.49 \\
\hline 6500 & 0.43 & 0.57 & 0.50 \\
\hline 7000 & 0.46 & 0.61 & 0.53 \\
\hline 7500 & 0.47 & 0.62 & 0.53 \\
\hline 8000 & 0.47 & 0.61 & 0.58 \\
\hline 8500 & 0.51 & 0.66 & 0.57 \\
\hline 9000 & 0.56 & 0.72 & 0.63 \\
\hline 9500 & 0.86 & - & - \\
\hline & & & \\
\hline
\end{tabular}


Dari tabel diatas dapat dibuat sebuah grafik perbandingan penggunaan bahan bakar terhadap putaran, sehingga terlihat perbedaan dari masing-masing bahan bakar yang digunakan.

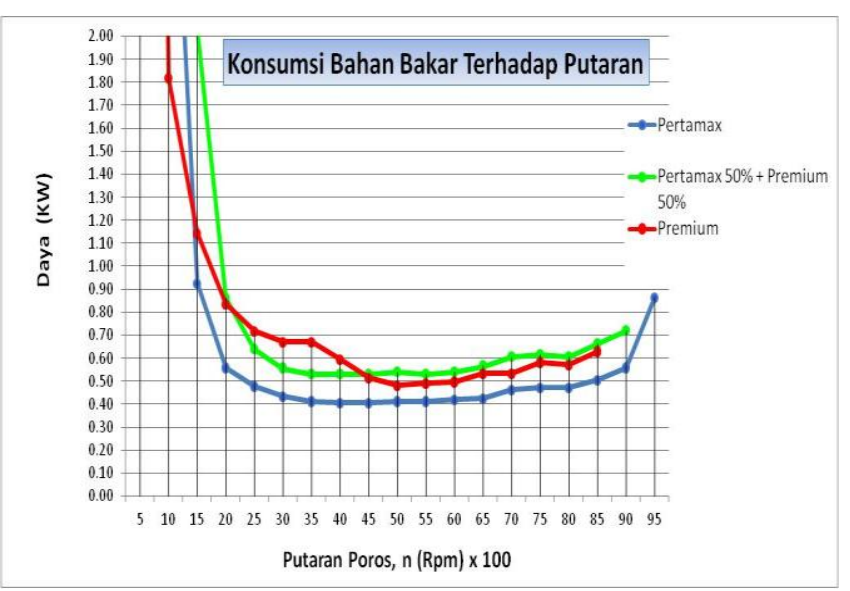

Gambar 4. Grafik hubungan konsumsi bahan bakar terhadap putaran

Dari grafik diatas menunjukkan hubungan pemakaian bahan bakar spesifik $(S F C)$ terhadap putaran (n), menunjukkan adanya penurunan komsumsi bahan bakar spesifik seiring dengan meningkatnya putaran poros untuk setiap konsentrasi. Untuk konsentrasi pertamax 100\% menunjukan bahwa pemakaian minimum bahan bakar spesifik (SFC) sebesar 0,41 $\mathrm{kg} / \mathrm{kWh}$ dicapai pada putaran 3500 dan pada putaran $5500 \mathrm{rpm}$. Pada konsentrasi campuran pertamax $50 \%$ + premium $50 \%$ menunjukan bahwa pemakaian minimum bahan bakar spesifik (SFC) sebesar 0,53 $\mathrm{kg} / \mathrm{kWh}$ dicapai pada putaran $3500 \mathrm{rpm}$ sampai 4500 dan pada putaran 5500 . Sedangkan untuk konsentrasi premium $100 \%$ menunjukan bahwa pemakaian minimum bahan bakar spesifik (SFC) sebesar $0,49 \mathrm{~kg} / \mathrm{kWh}$ dicapai pada putaran $6000 \mathrm{rpm}$.

\section{Kesimpulan}

Dari hasil analisa dan pembahasan data penelitian yang diperoleh maka dapat disimpulkan bahwa :

1. Pada komposisi bahan bakar pertamax $50 \%+$ premium $50 \%$ daya maksimum yang dihasilkan sebesar 6,5 kW; Pada putaran 3500 sampai 4500 dan pada putaran $5500 \mathrm{rpm}$ dengan konsumsi bahan bakar spesifik minimum sebesar $0,43 \mathrm{~kg} / \mathrm{kWh}$

2. Pada komposisi bahan bakar premium daya maksimum yang dapat dihasilkan sebesar 6,4 kW; pada putaran 5500 rpm dengan konsumsi bahan bakar spesifik minimum yang diperlukan sebesar $0,43 \mathrm{~kg} / \mathrm{kWh}$;

3. Pada komposisi bahan bakar pertamax daya maksimum yang dapat dihasilkan sebesar 6,6 kW; pada putaran 4000 sampai dengan $4500 \mathrm{rpm}$ dengan konsumsi bahan bakar spesifik minimum sebesar $0,41 \mathrm{~kg} / \mathrm{kWh}$;

\section{Daftar Pustaka}

[1].Lukman Hakim. 2004. Pengaruh Penggunaan Berbagai Jenis Bahan Bakar (Premium, Pertamax, Pertamax Plus) Terhadap Unjuk Kerja Motor Bensin 4 Langkah (4-tak). Undergraduate Theses from JIPTUMMPP, Engineering, Malang.

[2] Tri Hartono, Subroto, dan Nur Aklis, 2011. Penelitian Pengaruh Penggunaan Bahan Bakar Premium, Pertamax dan Pertamax Plus Terhadap Unjuk Kerja Motor Bakar Bensin. Jurusan Teknik Mesin Fakultas Teknik

Universitas Muhammadiyah Surakarta.

[3] G Haryono, 1987, Mengenal Motor Bakar, Penerbit Aneka Ilmu, Makassar.

[4] Arismunandar, Wiranto. 1983. Penggerak Mula Motor Bakar Torak. ITB, Bandung.

[5] Arismunandar, W. 2002. Motor Bakar Torak. Edisi 5, ITB, Bandung.

[6] Arismunandar, W, dan Tsuda, K. 2004. Motor Diesel Putaran Tinggi. Cetakan kesepuluh, Pradnya Paramita, Jakarta.

[7] Petrovsky,N,1989. Marine Internal Combustion Engines. Moscow: MIR Publishers. 